\title{
Elongate summit calderas as Neogene paleostress indicators in Antarctica
}

\author{
T. S. Paulsen ${ }^{1}$ and T. J. Wilson ${ }^{2}$ \\ ${ }^{1}$ Department of Geology, University of Wisconsin Oshkosh, 800 Algoma Boulevard, Oshkosh, WI 54901, USA (paulsen@uwosh.edu) \\ ${ }^{2}$ Byrd Polar Research Center and School of Earth Sciences, The Ohio State University, 108 Scott Hall, 1090 Carmack Road, Columbus, OH 43210 \\ (wilson.43@osu.edu)
}

\begin{abstract}
The orientations and ages of elongate summit calderas on major polygenetic volcanoes were compiled to document Miocene to Pleistocene $S_{h}$ (minimum horizontal stress) directions on the western and northern flanks of the West Antarctic rift system. Miocene to Pleistocene summit calderas along the western Ross Sea show relatively consistent ENE long axis trends, which are at a high angle to the Transantarctic Mountain Front and parallel to the $\mathrm{N} 77^{\circ} \mathrm{E} \mathrm{S}_{\mathrm{h}}$ direction at Cape Roberts. The elongation directions of many Miocene to Pleistocene summit calderas in Marie Byrd Land parallel the alignment of polygenetic volcanoes in which they occur, except several Pleistocene calderas with consistent NNE to NE trends. The overall pattern of elongate calderas in Marie Byrd Land is probably due to a combination of structurally controlled orientations and regional stress fields in which $\mathrm{S}_{\mathrm{h}}$ is oriented NNE to NE at a moderate to high angle to the trace of the West Antarctic rift system.
\end{abstract}

Citation: Paulsen, T. S. and T. J. Wilson (2007), Elongate summit calderas as possible Neogene paleostress indicators in Antarctica. in Antarctica: A Keystone in a Changing World - Online Proceedings of the $10^{\text {th }}$ ISAES, edited by A. K. Cooper and C. R. Raymond et al., USGS Open-File Report 2007-1047, Short Research Paper 072, 6 p.; doi:10.3133/of2007-1047.srp072

\section{Introduction}

Extensive Cenozoic alkali volcanic provinces occupy the West Antarctic rift system near its western flank, the Transantarctic Mountains, and along its northern flank, the Marie Byrd Land plateau (Fig. 1). Both provinces are comprised of trachytic to basaltic polygenetic shield and stratovolcanoes, and extensive fields of scattered basaltic cinder cones and lava flows (LeMasurier, 1990; Kyle, 1990). Although neotectonic faulting (LeMasurier, 1990; Davey and Brancolini, 1995; Jones, 1997; Salvini et al., 1997) and widespread active or young volcanism characterize the rift and rift flanks, little is known about the Neogene geodynamic evolution of the rift and riftflank uplift system. The nature of the Neogene to contemporary stress field in Antarctica is largely unknown because seismic events of sufficient magnitude for focal mechanism solutions have not been recorded (Reading, 2006) and there has been little drilling to obtain borehole stress data. Other possible indicators of the direction of the crustal stress field include the shapes of summit calderas on Antarctica's polygenetic volcanoes. It has recently been established that many summit calderas on the Earth's major Quaternary polygenetic volcanoes are elongate in a direction parallel to the contemporary minimum horizontal stress $\left(\mathrm{S}_{\mathrm{h}}\right)$ direction (Bosworth et al., 2000; Bosworth et al., 2003; Holohan, et al., 2005). No systematic study of the shapes of Antarctica's major summit calderas (Fig. 1) has been previously conducted, even though many of the summit calderas are clearly elongate (Fig. 2). This paper presents the first such analysis of elongate summit calderas on polygenetic volcanoes along the western and northern margins of the West Antarctic rift system. The goal is to obtain new constraints on stress field orientations during Miocene to Holocene volcanism, providing insight into the greater issue of the Neogene to contemporary Antarctic intraplate stress field.

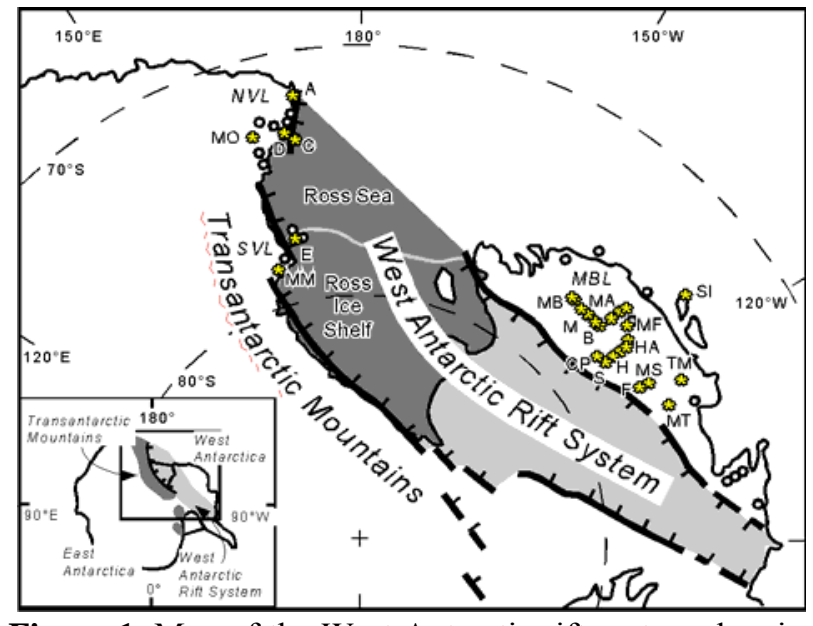

Figure 1. Map of the West Antarctic rift system showing the location of major volcanic centers (circles) and summit calderas (yellow stars) on polygenetic volcanoes on the western and northern flanks of the West Antarctic rift system in Antarctica (modified from LeMasurier, 1990). SVL, south Victoria Land; A, Cape Adare; B, Mount Bursey; C, Coulman Island; CP, Chang Peak; D, Daniell Peninsula; E, Mount Erebus; F, Mount Frakes; H, Mount Hartigan; HA, Mount Hampton; M, Mount Moulton; MA, Mount Andrus; MB, Mount Berlin; MBL, Marie Byrd Land; MF, Mount Flint; MM, Mount Morning; MO, Mount Overlord; MS, Mount Steere; MT, Mount Takahe; NVL, north Victoria Land; SI, Mount Siple; S, Mount Sidley; TM, Toney Mountain.

\section{Elongate summit calderas as paleostress indicators}

Summit calderas elongated parallel to $S_{h}$ tend to be common in extensional settings (Bosworth et al., 2000; Bosworth et al., 2003; Holohan, et al., 2005). Magma chambers are similar to vacant boreholes that develop borehole breakouts elongate in the direction of $\mathrm{S}_{\mathrm{h}}$ (Bell and Gough, 1979). In the case of calderas, crustal stress 
fields cause instabilities in the walls of subsurface magma chambers causing them to spall off and become elongate. Subsequent roof collapse associated with evacuation of the magma chamber then leads to a caldera elongate in the $\mathrm{S}_{\mathrm{h}}$ direction (Bosworth et al., 2000; Bosworth et al., 2003). Elongate calderas can also develop parallel to $S_{h}$ because of the influence of the stress field on ring fracture dip angle (Holohan et al., 2005). It is also possible for preexisting faults and fractures within the crust to control magma chamber growth and produce elongate calderas such that their elongation does not reflect $\mathrm{S}_{\mathrm{h}}$ (Bosworth et al., 2000; Bosworth et al., 2003; Holohan, et al., 2005). In areas lacking independent stress data, structural control on caldera elongation direction can be assessed by comparison to the trends of regional structures. In the absence of structural control on caldera shapes, the elongation direction of summit calderas can be used as an indicator of the $\mathrm{S}_{\mathrm{h}}$ direction and temporal constraints on the age of this direction can be provided if the age of caldera formation is known.
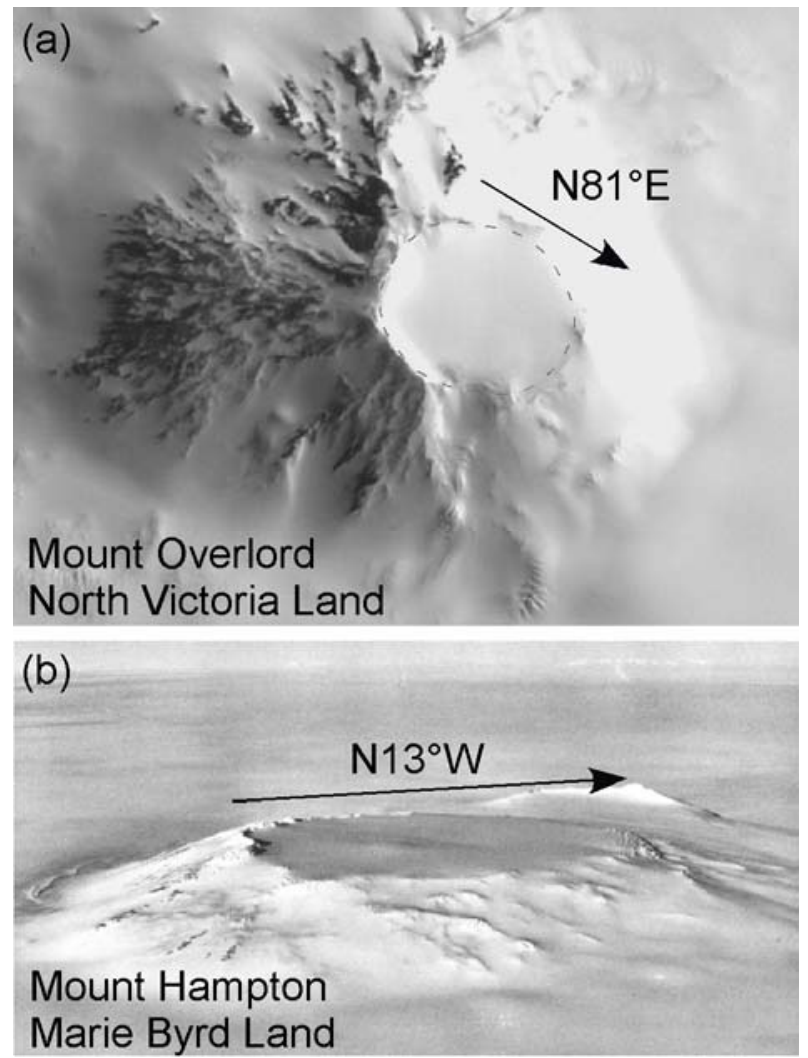

Figure 2. (a) Landsat TM image (25 $\mathrm{m}$ resolution) of the Mount Overlord elongate summit caldera in north Victoria Land. (b) Oblique aerial photograph of the highly elongate summit caldera on Mount Hampton in Marie Byrd Land (from LeMasurier and Thomson, 1990).

\section{Methods}

To determine whether calderas on Antarctica's major polygenetic volcanoes in the McMurdo Volcanic Group (along the western Ross Sea) and the Marie Byrd Land provinces record Neogene $S_{h}$ directions, we compiled the locations, ages, and, wherever possible, the shapes of summit calderas from LeMasurier and Thomson (1990) and more recent literature (Panter et al., 1994; Capponi et al., 1997; Harpel et al., 2004). We determined each caldera's long axis orientation, lengths of long and short axes, and axial ratio (long axis/short axis). We classified calderas with axial ratios $\geq 1.1$ as elongate and only compiled information on calderas retaining at least $2 / 3$ of their original rim. Calderas with entirely inferred shapes on geologic maps were excluded. The certainty of the shape of each caldera was classified into four quality rankings, where $\mathrm{A}>\mathrm{B}>\mathrm{C}>\mathrm{D}$ (Table 1). A- and B-ranked calderas have definite boundaries on geologic maps and are well defined on topographic maps, satellite imagery, or aerial photography. B-ranked calderas are those that have incomplete rims. C-ranked calderas have either definite or inferred boundaries on geologic maps, with shapes observed on topographic maps, satellite imagery, or aerial photography that are likely, but not certain. Dranked calderas have shapes that have been debated by previous authors. The age assigned to each caldera is the age of the youngest pre-caldera lavas, because these lavas mark the approximate timing of the evacuation of the magma chamber and subsequent caldera collapse. Table 1 lists each of the summit calderas, along with their relevant age and dimensional data.

Table 1. Location, Shape and Age of Elongate Calderas

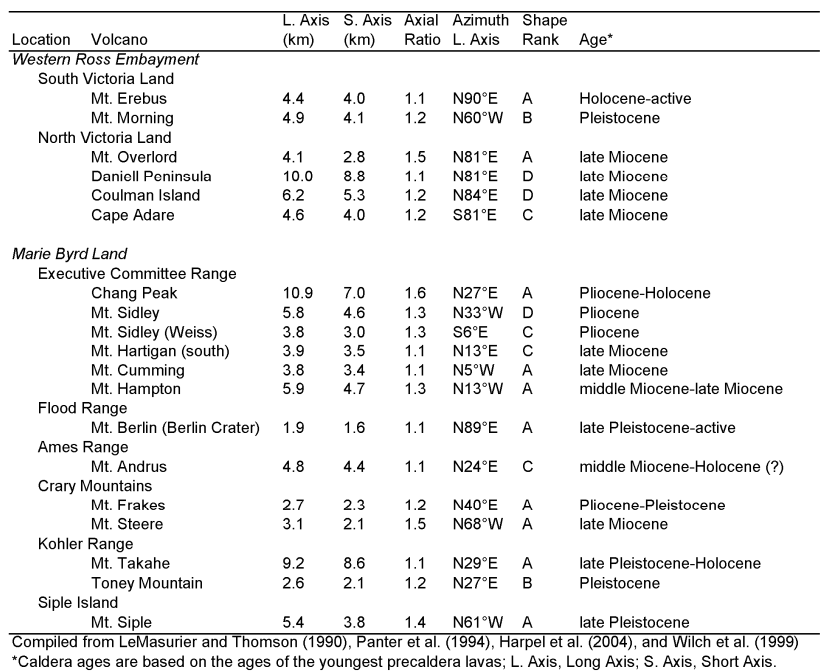

\section{Results}

Our compilation identified twenty-nine major shield volcanoes with summit calderas (Fig. 1). The majority of the calderas $(n=23)$ occur on the Marie Byrd Land plateau, with the remaining $(n=6)$ along the Transantarctic Mountains and the western Ross Sea. Overall, summit calderas range from 2 to $11 \mathrm{~km}$ in diameter (average diameter $=4.6 \mathrm{~km}$ ) and from 3 to $90 \mathrm{~km}^{2}$ in area (average area $=17 \mathrm{~km}^{2}$ ). Elongate calderas comprise nineteen of the twenty-nine summit calderas (Table 1) and these include ten A-ranked calderas, two B-ranked calderas, four C-ranked calderas, and three D-ranked calderas. Four 
of these are extremely elongate with axial ratios $\geq 1.4$ (e.g., Fig. 2), while the remaining fifteen have an average axial ratio of $\sim 1.2$.

\section{Discussion}

\section{Western Ross Sea \& Transantarctic Mountains}

All six summit calderas in the McMurdo Volcanic Group of the western Ross Sea and Transantarctic Mountains are elongate and show relatively consistent ENE long axis trends, with the possible exception of the calderas on Coulman Island and Daniell Peninsula. The long axes of the Pleistocene summit calderas on Mount Morning, Mount Erebus, and Cape Adare are perpendicular to the trend the Transantarctic Mountain Front fault zone, inferred to follow the coastline (e.g., Tessensohn and Worner, 1991). This suggests that the elongate summit caldera shapes are not structurally controlled and may be due to stress-induced magma chamber elongation. The $\mathrm{S} 30^{\circ} \mathrm{E}$ to $\mathrm{S} 60^{\circ} \mathrm{E}$ elongate summit caldera on Mount Morning is broadly similar to the $\mathrm{S} 62^{\circ} \mathrm{E}$ $\mathrm{S}_{\mathrm{h}}$ direction indicated by the Pleistocene vent alignments on its northern flank (Paulsen and Wilson, 2003). In north Victoria Land, the $\mathrm{N} 81^{\circ} \mathrm{E}$ elongate summit caldera on Mount Overlord is not parallel to the northeast or northwest faults that dominate the area (Salvini et al., 1997), suggesting that the caldera elongation direction records a Miocene $S_{h}$ direction. If the calderas on Coulman Island and Daniell Peninsula are elongate NNE as suggested by Capponi et al. (1997), they are likely structurally controlled by NNE trending faults in the area (Salvini et al., 1997). Alternatively, the $\sim \mathrm{N} 80^{\circ} \mathrm{E}$ elongation direction of the Coulman Island and Daniell Peninsula calderas, as mapped by McIntosh and Kyle (1990), and the $S 81^{\circ} \mathrm{E}$ elongation direction of the caldera on Cape Adare, could reflect Miocene $\mathrm{S}_{\mathrm{h}}$ directions. Regionally, the Miocene and Pleistocene to Holocene elongate summit calderas in the McMurdo Volcanic Group have consistent long axis trends. This may reflect a uniform orientation for $\mathrm{S}_{\mathrm{h}}$ since $\sim 7$ Ma. This direction is parallel to the contemporary $\mathrm{N} 77^{\circ} \mathrm{E} \mathrm{S}_{\mathrm{h}}$ stress direction determined from borehole breakouts and drilling induced fractures at Cape Roberts along the Transantarctic Mountain Front (Fig. 3) (Jarrard et al., 2001; Wilson and Paulsen, 2001).

\section{Marie Byrd Land}

Many of the polygenetic volcanoes (and their associated calderas) in Marie Byrd Land occur along N/S and E/W volcanic chains (LeMasurier and Rex, 1989) (Fig. 4). Our analysis indicates that many, but not all, of the long axes of elongate calderas are parallel to the volcanic chains and are therefore probably structurally controlled. Exceptions to this include the Pleistocene calderas on Chang Peak, Toney Mountain, Mount Takahe, and Mount Siple, and the Miocene caldera on Mount Steere. The Pliocene to Pleistocene calderas on Chang

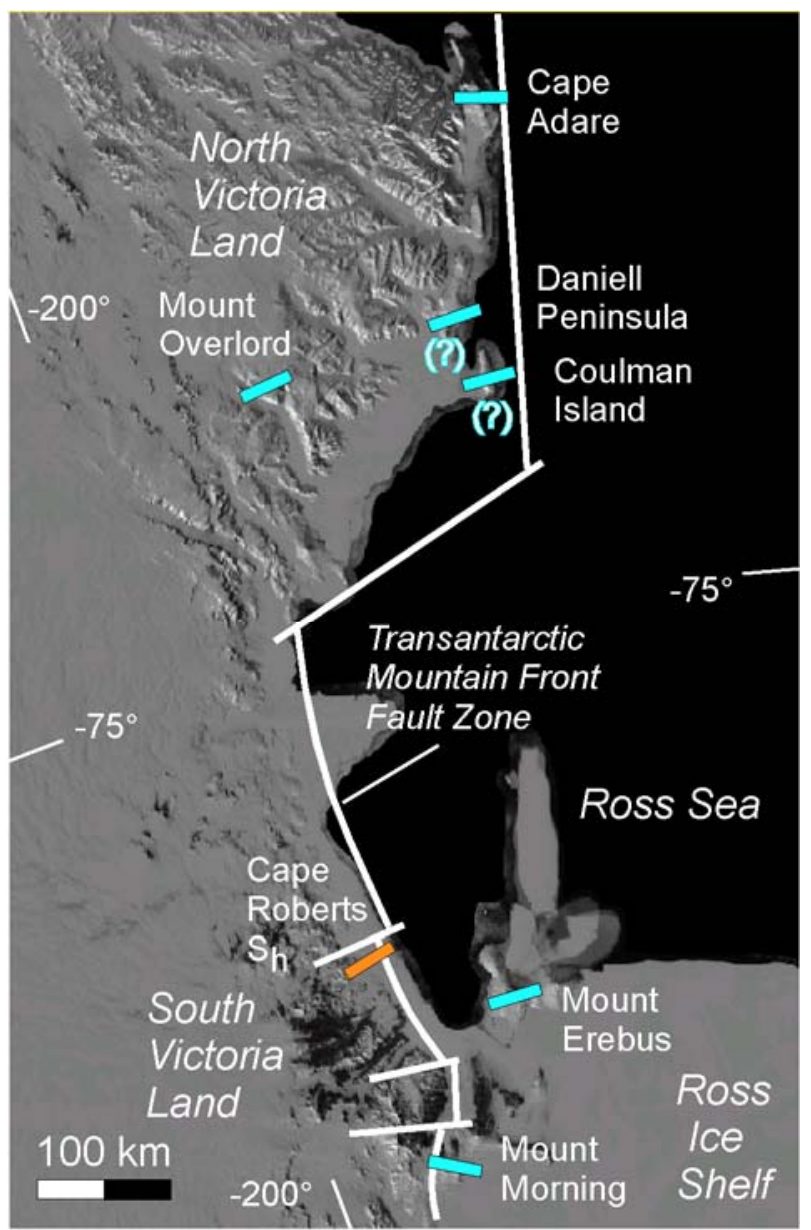

Figure 3. MODIS image showing elongation directions (blue lines) of summit calderas in the McMurdo Volcanic Group along the western flank of the West Antarctic rift system (MODIS image from Haran et al., 2005). Note that the elongation directions are parallel to the contemporary $\mathrm{S}_{\mathrm{h}}$ direction (orange line) documented by borehole and core fractures at Cape Roberts.

Peak, Toney Mountain, Mount Takahe, and Mount Frakes may have a uniform NNE- to NE-elongation direction due to a regionally consistent Pliocene to Pleistocene stress field in which $\mathrm{S}_{\mathrm{h}}$ was (is?) oriented $\sim \mathrm{NNE}$ to NE. A NNEto NE-trending $\mathrm{S}_{\mathrm{h}}$ direction is consistent with both voluminous volcanism along $\sim \mathrm{E}-\mathrm{W}$-striking magmatic conduits (e.g., Flood Range, the Usas escarpment, and the southern portions of the Executive Committee Range and the Crary Mountains) and development of E-W elongation of volcanic edifices as a whole (Toney Mountain, Mount Takahe, and Mount Siple).

LeMasurier and Rex (1989) suggested a mantle plume caused doming in the center of the Marie Byrd Land province and that volcanism propagated outward along reactivated faults in a radial pattern. Other authors have questioned the plume origin for Marie Byrd Land volcanoes (e.g., Finn et al., 2005) and the timing of uplift may be older than the age of volcanism in the province 


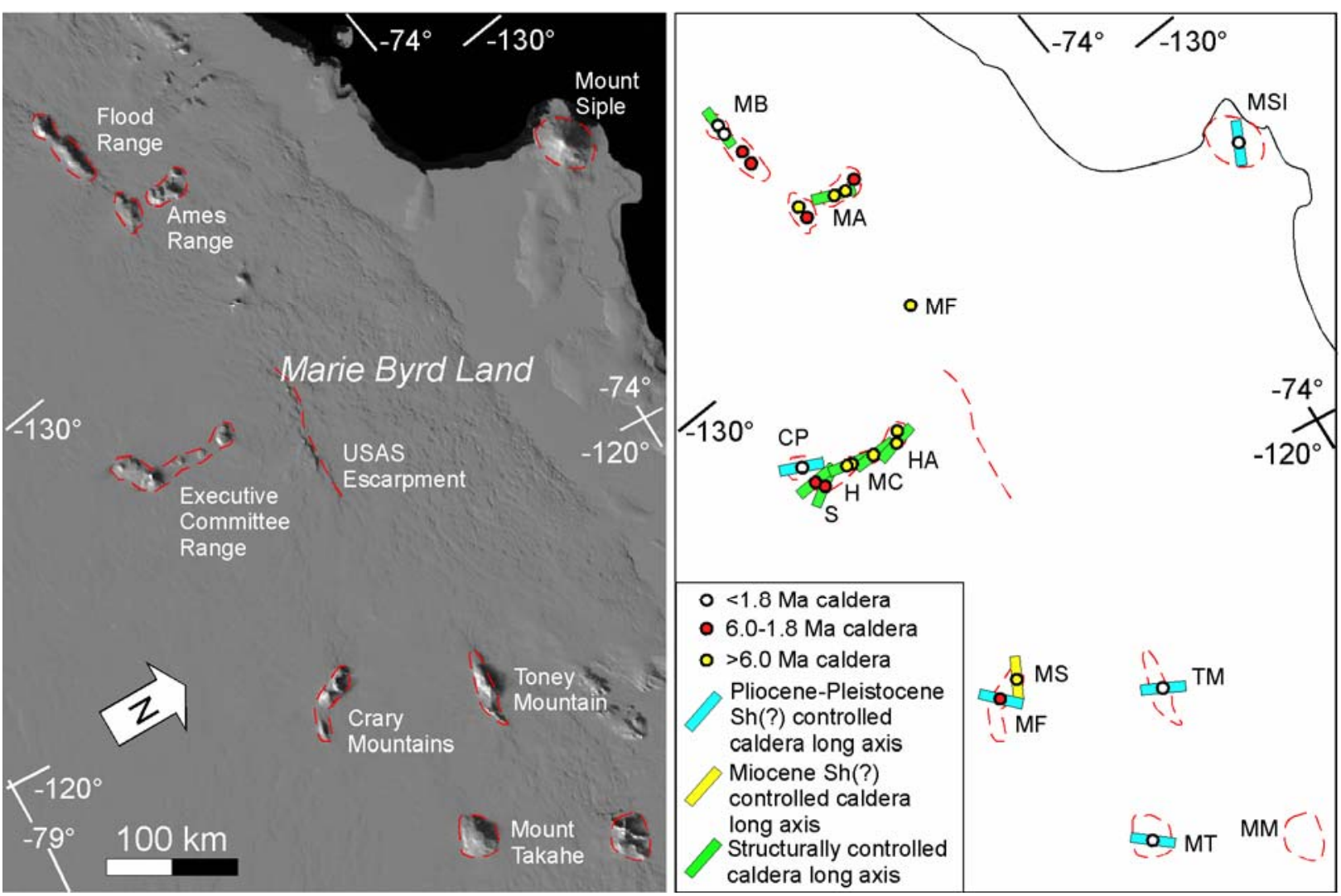

Figure 4. (a) MODIS image showing volcanic landforms in Marie Byrd Land province along the northern flank of the West Antarctic rift system (MODIS image from Haran et al., 2005). (b) Map of the major calderas in Marie Byrd Land Province with ages and long axis orientations (blue, yellow and green lines). Note that elongation directions are in many cases subparallel to N/S and E/W chains of polygenetic volcanoes, suggesting that their shapes are controlled by subsurface structures. Blue lines indicate Pliocene to Pleistocene caldera elongation directions that may reflect Pliocene to Pleistocene $\mathrm{S}_{\mathrm{h}}$ directions. MC, Mount Cumming; MM, Mount Murphy; other abbreviations same as Fig. 1.

(Luyendyk et al., 2001). Winberry and Anandakrishnan (2004) showed that the Marie Byrd Land 'dome' encompasses a broad region that is elongate in an E-W direction, which is subparallel to the inferred trace of the West Antarctic rift system (Fig. 1). The thin crust on the edge of this elevated area in Marie Byrd Land led Winberry and Anandakrishnan (2004) to suggest significant crustal extension occurred within the Marie Byrd Land region due to rifting within the West Antarctic rift system. The timing of uplift of the Marie Byrd Land dome notwithstanding, the uniform NNE- to NE-trending $\mathrm{S}_{\mathrm{h}}$ directions implied by the Pliocene to Pleistocene calderas are at moderate to high angles to the E-W traces of the Marie Byrd Land dome and the West Antarctic rift system, and are broadly similar to the rift-normal $S_{h}$ directions indicated by elongate calderas along the western flank of the rift system in the western Ross Sea along the Transantarctic Mountains. In a rift context, the $\mathrm{N}-\mathrm{S}$ alignments of polygenetic volcanoes in Marie Byrd Land may reflect volcanism along major accommodation zones within the West Antarctic rift system. If this is the case, the apparent en echelon pattern of the caldera long axes of Mount Hampton, Mount Cumming, and Mount Sidley in the Executive Committee Range (Fig. 4) could reflect magma ascension along tensional fractures (Panter et al., 1994) that formed in response to left-lateral strikeslip movement that accommodates differences in extension along the rift system. This interpretation requires active Mio-Pliocene rifting, which has been questioned by previous authors (Finn et al., 2005). Alternatively, the N-S alignments of polygenetic volcanoes could reflect the exploitation of earlier formed faults in basement rocks (LeMasurier and Rex, 1989) by ascending magmas in the Miocene to Pliocene, possibly under stress fields that differed in orientation or magnitude from the Pliocene to Pleistocene stress field in which $S_{h}$ was (is?) oriented NNE to NE.

\section{Triggering mechanisms for caldera collapse events}

Bosworth et al. (2003) noted that the sudden appearance of Pleistocene caldera collapse events in the Kenya rift valley correlates with a rapid change in the $S_{h}$ direction and an increase in the magnitude of the maximum horizontal stress $\left(\mathrm{S}_{\mathrm{H}}\right)$. Caldera collapse of felsic shield volcanoes in Japan has also been associated with changes in the magnitudes of the horizontal stresses (Bosworth et al. 2003). Presumably changes in the direction and/or magnitude of crustal stresses can cause 
magma chambers to become unstable and subsequently collapse. Similarly, there may have been changes in the stress field triggering caldera collapse events on Antarctic volcanoes. A particularly intriguing possibility is that some Antarctic calderas may have collapsed due to changes in glacial loading, which can cause dramatic changes in the magnitude of vertical and horizontal stresses. Glacial loading and unloading has been argued to suppress or promote faulting in extensional and compressional settings (Hetzel and Hampel, 2005; Wu and Hasegawa, 1996). Such geodynamic changes likely occurred in Antarctica during deglaciation after the Last Glacial Maximum. In the Ross Sea, the grounding line has retreated $\sim 1300 \mathrm{~km}$ since the Last Glacial Maximum around 20,000 years before present and passed Ross Island from 7600 to 6800 years before present (Conway et al., 1999). Current age constraints on the timing of the collapse of Mount Erebus' caldera range from 25,000 to 11,000 Ka (Harpel et al., 2004), and therefore allow for the possibility that stress field changes related to changes in ice load caused magma chamber instability and subsequent collapse. Collapse of pre-Holocene calderas elsewhere in Antarctica may also record past changes in ice load or tectonic stresses, but the relatively poor constraints on the timing of caldera collapse events, ice sheet loading and unloading, and paleostress fields currently precludes assessing this possibility in more detail.

\section{Summary}

Elongate Miocene to Pleistocene summit calderas on polygenetic calderas on the western flank of the West Antarctic rift system indicate a consistent ENE $\mathrm{S}_{\mathrm{h}}$ direction oriented at a high angle to the Transantarctic Mountain Front and parallel to the contemporary stress direction measured at Cape Roberts. On the northern flank of the rift system in Marie Byrd Land, elongate Miocene to Pleistocene calderas record a combination of structurally controlled orientations and regional stress fields in which $\mathrm{S}_{\mathrm{h}}$ is oriented NNE to NE at a moderate to high angle to the traces of the Marie Byrd Land dome and the West Antarctic rift system.

Acknowledgments. This work was funded by NSF grant OPP-990970 to T. Wilson and NSF grant OPP-9910879 to T. Paulsen. We thank Thomas Wilch, Kurt Panter, and Christie Demosthenous for helpful reviews that clarified this manuscript, and Paul Fitzgerald for editorial handling of this manuscript.

\section{References}

Bell, J. S., and Gough, D. I. (1979), Northeast-southwest compressive stress in Alberta: Evidence from oil wells. Earth and Planetary Science Letters, v. 45, p. 475-482.

Bosworth, W., K. Burke, M. Strecker (2000), Magma chamber elongation as an indicator of intraplate stress field orientation: Borehole breakout mechanism and examples from the Late Pleistocene to Recent Kenya Rift Valley, in Stress, Strain, and Structure, A Volume in Honor of W.D. Means, edited by M.W. Jessell and J.L. Urai, J. Virtual Explorer, 2.

Bosworth, W., K. Burke, M. Strecker (2003), Effects of stress fields on magma chamber stability and the formation of collapse calderas, Tectonics, 22, 1042.
Capponi, G., M. Meccheri, G. Oggiano, R. Casnedi, L. Crispini, G. Kleinschmidt, A. Montrasio, P.C. Pertusati, N.W. Roland, F. Salvini, M. Schmidt-Thomé, and F. Tessensohn, (1997), Coulman Island Quadrangle (Victoria Land). Antarctic Geological 1:250 000 Map Series. Museo Nazionale dell'Antartide.

Conway, H., B.L. Hall, G.H. Denton, A.M. Gades, and E.D. Waddington (1999), Past and future grounding line retreat of the West Antarctic ice sheet, Nature, 286, 280-283.

Davey, F.J., and G. Brancolini (1995), The Late Mesozoic and Cenozoic structural setting of the Ross Sea Region, in Geology and Seismic Stratigraphy of the Antarctic Margin, Antarctic Res. Ser., vol. 68, edited by A.J. Cooper, P.F. Barker, and G. Brancolini, pp. 167-182 AGU, Washington D.C.

Finn, C.A., R.D. Muller, and K.S. Panter (2005), A Cenozoic diffuse alkaline magmatic province (DAMP) in the southwest Pacific without rift or plume origin, Geochemistry, Geophysics, Geosystems, 6, doi:10.1029/2004GC000723.

Haran, T., J. Bohlander, T. Scambos, and M. Fahnestock compilers (2005), MODIS mosaic of Antarctica (MOA) image map. Boulder, CO, USA: National Snow and Ice Data Center. Digital media.

Harpel, C.J., P.R. Kyle, R.P. Esser, W.C. McIntosh, and D.A. Caldwell (2004), 40Ar/39Ar dating of the eruptive history of Mount Erebus, Antarctica: summit flows, tephra, and caldera collapse, Bull. Volcanol., 66, 687-702.

Hetzel, R., and A. Hampel (2005), Slip rate variations on normal faults during glacial-interglacial changes in surface loads, Nature, 435, 8183.

Holohan, E.P., V.R. Troll, T.R. Walter, S. Munn, S. McDonnell, and Z.K. Shipton (2005), Elliptical calderas in active tectonic settings: an experimental approach, J. Volcanol. and Geotherm. Res., 144, 119136.

Jarrard, R. D., D. Moos, T. Wilson, C.B. Bücker, and T. Paulsen (2001), Stress patterns observed by borehole televiewer logging of the CRP-3 drillhole, Victoria Land Basin, Antarctica, Terra Antartica, 8, 197204.

Jones, S. (1997), Late Quaternary faulting and neotectonics, South Victoria Land, Antarctica, J. Geol. Soc. London, 154, 645-652.

Kyle, P.R. (1990), McMurdo Volcanic Group, western Ross Embayment: Introduction, in Volcanoes of the Antarctic Plate and southern Oceans, Antarctic Res. Ser., vol. 48, edited by W.E. LeMasurier and J.W. Thomson, pp. 19-25, AGU, Washington D.C.

LeMasurier, W.E. (1990), Late Cenozoic volcanism on the Antarctic plate--An overview, in Volcanoes of the Antarctic Plate and Southern Oceans, Antarctic Research Series, vol. 48, edited by W.E. LeMasurier and J.W. Thomson, pp. 1-19, AGU, Washington D.C.

LeMasurier, W.E., and D.C. Rex (1989), Evolution of linear volcanic ranges in Marie Byrd Land, West Antarctica, J. Geophys. Res., 94, 7223-7236.

LeMasurier, W.E., and J.W. Thomson (1990), editors, Volcanoes of the Antarctic Plate and Southern Oceans, Antarctic Research Series, vol. 48, 487 p., AGU, Washington D.C.

Luyendyk, B. P., C. C. Sorlien, D. S. Wilson, L. R. Bartek, and C. S. Siddoway (2001), Structural and tectonic evolution of the Ross Sea rift in the Cape Colbeck region, Eastern Ross Sea, Antarctica, Tectonics, 20, 933-958.

McIntosh, W.C., and P.R. Kyle, (1990), A.4. Coulman Island, in LeMasurier, W.E., and Thomson, J.W., eds., Volcanoes of the Antarctica Plate and Southern Oceans, American Geophysical Union, Antarctica Research Series, v. 48, p. 43-45.

Panter, K.S., W.C. McIntosh, and J.L. Smellie (1994), Volcanic history of Mount Sidley, a major alkaline volcano in Marie Byrd Land, Antarctica, Bull Volcanol., 56, 361-376.

Paulsen, T., and T. Wilson (2003), Volcanic cone alignments and the intraplate stress field in the Mount Morning region, South Victoria Land. $9^{\text {th }}$ International Symposium on Antarctic Earth Sciences Programme and Abstracts, Potsdam, Germany, p. 251.

Reading, A.M. (2006), On seismic strain-release within the Antarctic Plate. in Antarctica Contributions to Global Earth Sciences, International Symposium on Antarctic Earth Sciences, vol. 9, edited by D. Damaske, G. Kleinschmidt, H. Miller, and F. Tessensohn, pp. 351-356, Springer-Verlag, Berlin-Heidelberg. 
Salvini, F., G. Brancolini, M. Busetti, F. Storti, F. Mazzarini, and F. Coren (1997), Cenozoic geodynamics of the Ross Sea region, Antarctica, J. Geophys. Res., 102, 24,669-24,696.

Tessensohn, F., and G. Wörner (1991), The Ross Sea rift system, Antarctica: structure, evolution and analogues, in Geological Evolution of Antarctica, edited by M.R.A. Thomson, J.A. Crame, and J.W. Thomson, pp. 273-277, Cambridge Univ. Press, New York.

Wilch, T.I., McIntosh, W.C., and N.W. Dunbar (1999), Late Quaternary volcanic activity in Marie Byrd Land: Potential 40Ar/39Ar-dated time horizons in West Antarctic ice and marine cores, Geol. Soc. Amer. Bull., 111, 1563-1580.

Wilson, T., and T. Paulsen (2001), Fault and Fracture patterns in the CRP-3 core, Victoria Land Basin, Antarctica, Terra Antartica, 8, 177196.

Winberry, J. P., and S. Anandakrishnan (2004), Crustal structure of the West Antarctic rift system and Marie Byrd Land hotspot, Geology, 32, 922-980.

Wu, P., and H.S., Hasegawa (1996), Induced stresses and fault potential in eastern Canada due to a disc load: a preliminary analysis, Geophys. J. Int., 125, 415-430. 